(C) 2017, THE AUTHORS. Published by FASS and Elsevier Inc. on behalf of the American Dairy Science Association ${ }^{\circledR}$.

This is an open access article under the CC BY-NC-ND license (http://creativecommons.org/licenses/by-nc-nd/3.0/).

\title{
Effect of a single injection of cabergoline at dry off on udder characteristics in high-yielding dairy cows
}

\author{
S. Bertulat, ${ }^{*}$ N. Isaka, $†$ A. de Prado, $†$ A. Lopez, $†$ T. Hetreau, $\ddagger$ and W. Heuwieser*1 \\ ${ }^{*}$ Clinic for Animal Reproduction, Faculty of Veterinary Medicine, Freie Universität Berlin, Koenigsweg 65, 14163 Berlin, Germany \\ †CEVA Santé Animale, 10 Avenue de la Ballastière, 33500 Libourne, France \\ ¥Centre d'élevage Lucien Biset, 845 Route de l'École d'Agriculture, 74330 Poisy, France
}

\section{ABSTRACT}

In recent years, relationships between high milk yield at dry off, higher prevalence for new intramammary infections, and stress were evaluated. Considering increasing milk yield, dry off methods need to be refined to ensure udder health and animal welfare, especially in high-yielding dairy cows. The present work evaluated the effect of a single cabergoline injection (Velactis, Ceva Santé Animale, Libourne, France) at dry off on udder pressure, milk leakage, and signs of udder pain after dry off. A total of 234 high-yielding $(\geq 16 \mathrm{~kg}$ of milk/d) dairy cows was enrolled $7 \mathrm{~d}$ before and followed up until $14 \mathrm{~d}$ after dry off. Cows were dried off without preparation (i.e., no feed change or intermittent milking before dry off) and treated with a single i.m. injection of $5.6 \mathrm{mg}$ of cabergoline $(\mathrm{n}=115)$ or placebo $(\mathrm{n}=119)$ after last milking. Udder characteristics were measured $4 \mathrm{~d}$ before (i.e., before and after milking) and $1,2,3,7,10$, and $14 \mathrm{~d}$ after dry off. Udder pressure was evaluated utilizing a hand-held dynamometer. Milk leakage and signs of udder pain were noted as binary variables. Whereas udder pressure baseline values after last milking did not differ between treatment groups $(0.541 \pm 0.15 \mathrm{~kg})$, cabergoline significantly reduced udder pressure in primiparous but not in multiparous cows after dry off. Differences between cabergoline- and placebo-treated primiparous cows could be evaluated until $3 \mathrm{~d}$ after dry off. The first day after dry off, udder pressure in placebo- and cabergoline-treated cows increased by $115 \%$ and $42.3 \%$, respectively. Whereas pressure values in placebo cows were highest on the first day after dry off $(1.16 \pm 0.61 \mathrm{~kg})$ and slowly decreased afterward, udder pressure in cows treated with cabergoline had a slower increase and peak only $2 \mathrm{~d}$ after dry off $(0.94 \pm 0.44 \mathrm{~kg})$. Furthermore, cabergoline caused a reduction of milk leakage, a known factor

Received August 6, 2015.

Accepted December 1, 2016.

${ }^{1}$ Corresponding author: w.heuwieser@fu-berlin.de for new intramammary infections. Only $11.3 \%$ of cows treated with cabergoline showed milk leakage compared with $21.0 \%$ placebo-treated cows. Additionally, cows with placebo treatment were 2.8 times as likely to show signs of udder pain compared with cows treated with cabergoline. An effect of cabergoline on udder pressure, milk leakage, and udder pain was limited to the first week after dry off. Our data provide evidence that a single injection of cabergoline reduces risk factors for udder health and animal welfare problems around dry off in high-yielding dairy cows with more than $16 \mathrm{~kg}$ of milk/d. Further research is warranted, however, to investigate if cabergoline at dry off can also be used to reduce new intramammary infection rates and improve animal welfare after dry off.

Key words: dairy cow, dry off, cabergoline, milk leakage, prolactin-release inhibitor

\section{INTRODUCTION}

It is well documented that dry cow management and the dry period can have a distinct effect on animal health (Kim and Suh, 2003), milk production (Annen et al., 2004; Andersen et al., 2005), and fertility (Beever, 2006) of dairy cows in the following lactation. Although milk yield per cow per year has increased during the last 4 decades by 30 to $50 \%$ (Thornton, 2010; Zobel et al., 2015), dry off procedures hardly changed. A sudden dry off is still the most common management practice on commercial dairy farms (Dingwell et al., 2001; Bertulat et al., 2015), whereas milk yield at dry off changed from below 9 (Natzke et al., 1975) to 24 to $30 \mathrm{~kg} / \mathrm{d}$ (Annen et al., 2004; Chapinal et al., 2014).

Several studies indicated adverse effects of high milk yield before dry off. Bertulat et al. (2013) analyzed the effect of milk yield on udder pressure, milk leakage, and stress levels after sudden dry off. It was shown that high-yielding dairy cows had higher udder pressure and elevated stress levels compared with low-yielding cows. This association between milk yield, udder pressure, and discomfort (i.e., altered standing-lying behavior) 
after cessation of milking was described by O'Driscoll et al. (2011) as well, albeit not in cows that were dried off but cows with an omission of a scheduled milking event. Another study implicated that a sudden dry off in high-yielding dairy cows provokes signs of distress, which were associated with neutrophilia in milk (Silanikove et al., 2013).

Rajala-Schultz et al. (2005) demonstrated a relationship between milk yield and IMI after dry off. The authors argued that high milk yield causes milk leakage (Rovai et al., 2007), and therefore a slower formation of the keratin plug. Consequently, the teat canal remains open for bacterial entry for a longer period of time (Dingwell et al., 2004; Rajala-Schultz et al., 2005). Milk leakage is a major cause for IMI both during lactation and after dry off (Schukken et al., 1993; Waage et al., 1998; Pezeshki et al., 2010), and has been demonstrated to occur more often after sudden dry off than after gradual cessation of milking (Zobel et al., 2013). In cows with sudden dry off the prevalence was higher in high- compared with low-yielding cows (Bertulat et al., 2013). Considering these relationships and the ongoing increase of milk yield, strategies to facilitate an efficacious dry off procedure and to reduce udder pressure and milk leakage are necessary.

Several management methods are known to reduce milk secretion before and immediately after dry off (Bertulat et al., 2015). Valizaheh et al. (2008) compared the effect of 2 different hay diets before dry off and showed that both were efficient in decreasing milk production. These results were supported by Tucker et al. (2009), who demonstrated that feed restriction and gradual cessation of milking had a negative effect on milk yield before dry off. Furthermore, Tucker et al. (2009) reported a decreased prevalence of milk leakage and IMI after dry off in cows with reduced feed intake, but not after gradual cessation of milking. In contrast to Tucker et al. (2009), Zobel et al. (2013) found less milk leakage in cows with gradual dry off compared with cows that were dried off abruptly. Milk yield before dry off, however, was distinctively higher than in the study population used by Tucker et al. (2009), and both groups (i.e., abrupt and gradual dry off) were fed a low-energy diet. An explanation for these finding was provided by Bushe and Oliver (1987), who investigated the effect of different dry off methods on milk composition after dry off and the ability to inhibit growth of coliform mastitis pathogens and, thus, prevent new IMI. Whereas no differences between cows that were dried off abrupt or by gradual cessation of milking were noted, cows that were milked intermittently and fed a hay diet had higher concentrations of somatic cells, lactoferrin, IgG, and BSA and had a higher inhibitory activity to in vitro growth of Escherichia coli (Bushe and Oliver, 1987).

Feed restriction, however, has several disadvantages. Tucker et al. (2009), as well as Valizaheh et al. (2008), reported that cows exposed to reduced feed intake had a greater frequency of vocalization and probably suffered from hunger. Furthermore, severe feed restriction (i.e., straw diet) caused increased cortisol levels, affected nonesterified fatty acid, BHB, and urea concentrations (Odensten et al., 2005, 2007). These metabolic imbalances indicate a negative energy balance that might cause an impairment of udder defense mechanisms (O'Rourke, 2009). In the studies presented by Odensten et al. $(2005,2007)$, udder health, however, was neither improved nor deteriorated by feed restriction.

Recently, some studies explored pharmacological options to hasten mammary gland involution. Casein hydrolysate was shown to have a positive effect on udder pressure and resting behavior in high-yielding dairy cows (Leitner et al., 2007) and hastened mammary gland involution (Ponchon et al., 2014). Furthermore, other studies have shown that the innate immune system of the mammary gland is activated by casein hydrolysate, which might potentially prevent bacterial infection (Silanikove et al., 2005). To our knowledge, data from field studies on the efficacy of casein hydrolysate, however, have not been published.

Furthermore, systemic application of prolactinrelease inhibitors and their effects on mammary gland involution has been investigated. Prolactin-release inhibitors are dopamine D2 receptor agonists, inhibiting the release of prolactin in the pituitary gland. As a result, the galactopoietic effect of prolactin is countered (Lacasse et al., 2012). Quinagolide, a prolactin-release inhibitor shown to reduce milk production (Lacasse et al., 2012; Ollier et al., 2013, 2014), improved resistance to IMI after dry off (Ollier et al., 2015). Although these results are promising, the treatment regimen (i.e., once or twice daily for several days) is hardly adequate for field applications (Ollier et al., 2015).

Cabergoline $(\mathbf{C A B})$ is a prolactin-release inhibitor approved to treat false pregnancies in bitches in most European countries (Gobello et al., 2001). Several studies investigated the effect of $\mathrm{CAB}$ on milk secretion (Jöchle et al., 1987) and lactation in healthy bitches and those with pseudopregnancies (Arbeiter et al., 1988; Harvey et al., 1997). Furthermore, a case study (Arlt et al., 2011) mentioned the application of $\mathrm{CAB}$ in goats with inappropriate lactation syndrome. Therefore, the objective of our study was to evaluate the effect of a single $\mathrm{CAB}$ injection at dry off on udder pressure, milk leakage, and udder pain after dry off in high-yielding dairy cows. 
Table 1. Farm and cow data

\begin{tabular}{|c|c|c|c|c|c|c|c|c|}
\hline $\begin{array}{l}\text { Farm } \\
\text { number }\end{array}$ & Country & $\begin{array}{c}\text { Average } \\
\text { number of } \\
\text { lactating cows }\end{array}$ & $\begin{array}{l}\text { Average } \\
\text { 305-d lactation } \\
\text { (in kg) }\end{array}$ & \multicolumn{4}{|c|}{ Study population $(\mathrm{n}=263)$} & $\begin{array}{c}\text { Average milk } \\
\text { yield at dry } \\
\text { off (in kg) }\end{array}$ \\
\hline 1 & Germany & 350 & 8,180 & 16 & 16 & 15 & 17 & $19.8 \pm 3.1$ \\
\hline 2 & France & 245 & 8,730 & 10 & 10 & 4 & 16 & $18.0 \pm 2.3$ \\
\hline 5 & France & 60 & 9,400 & 9 & 9 & 11 & 7 & $22.0 \pm 2.9$ \\
\hline 6 & France & 40 & 9,300 & 5 & 6 & 4 & 7 & $23.1 \pm 3.5$ \\
\hline 7 & France & 48 & 9,100 & 5 & 6 & 6 & 5 & $19.6 \pm 2.3$ \\
\hline $8^{3}$ & France & 60 & 7,500 & 2 & 2 & 2 & 2 & $22.0 \pm 3.6$ \\
\hline 9 & France & 85 & 8,000 & 7 & 7 & 5 & 9 & $18.2 \pm 1.8$ \\
\hline 10 & France & 98 & 6,700 & 8 & 8 & 5 & 11 & $18.1 \pm 1.7$ \\
\hline $11^{3}$ & France & 85 & 8,700 & 1 & 1 & 1 & 1 & $18.3 \pm 2.1$ \\
\hline Total & & & & 130 & 133 & 122 & 141 & \\
\hline
\end{tabular}

${ }^{1}$ Cabergoline-treated cows.

${ }^{2}$ Placebo-treated cows.

${ }^{3}$ Not included in the final analysis due to low number of cows provided for the study.

\section{MATERIALS AND METHODS}

Analyzed data came from a study designed and performed in compliance with various directives (i.e., 2001/82/EC, 2004/28/EC, and 2009/09/EC; European Commission Health and Consumers Directorate-General, 2016) of the European Parliament. A test permit was granted by the local veterinary authorities.

\section{Animals and Experimental Design}

Between September 2010 and April 2011, a total of 263 healthy, late-lactating ( $59 \pm 15$ d before calving; mean \pm SD) Holstein-Friesian (i.e., 86\%) and Montbeliarde (i.e., 14\%) dairy cows from 16 farms in France, Germany, and Hungary were included in the study (Table 1). Farms were selected based on herd size, milk yield, and a reasonable driving distance for the investigators. Cows were enrolled $7 \mathrm{~d}$ before and followed up until $14 \mathrm{~d}$ after dry off. Inclusion criteria were an average milk yield of more than $16 \mathrm{~kg}$ for $7 \mathrm{~d}$ before dry off and an expected calving date more than $35 \mathrm{~d}$ after dry off. Milk yield was measured by milk meters installed in all milking parlors or automatic milking systems. All cows were housed in freestall barns with or without access to pastures, were fed a TMR, and had ad libitum access to fresh water. On 14 farms, lactating cows were milked twice daily in a milking parlor. Cows on 2 farms were milked thrice daily in a milking parlor or by automatic milking system, respectively. Relevant cow data (i.e., breed, age, parity, DIM, date of insemination) were provided by the farm managers. Milk yield was measured by milk meters integrated in the milk parlor, and 305-d lactation yield was calculated by the herd-management software. Data on SCC were copied from the last DHI record before dry off. These records were provided by different local DHIA from Germany, France, and Hungary that were responsible for DHI tests in the study herds.

General and udder examinations were carried out 7 d before dry off, at the day of dry off (including California mastitis test), and when the cow completed the study. Cows suffering from any infectious or metabolic diseases, cows with 1 or more nonfunctional quarters, clinical mastitis, teat, or udder lesions, or a California mastitis test result of $\geq 2$ were not included or retrospectively withdrawn from the study. All cows were dried off without any preparation (i.e., feed change in the weeks before dry off or intermittent milking) and transferred to a separate dry cow pen after last milking. Whereas each quarter was treated with an intramammary antibiotic dry cow therapy, external and internal teat sealer were not allowed for their known effect on milk leakage. After dry off, cows on all farms received a low-energy TMR.

After the last milking, cows received a single i.m. injection of $5 \mathrm{~mL}$ of a solution containing $5.6 \mathrm{mg}$ of CAB (Velactis, Ceva Santé Animale, Libourne, France) 
or an equivalent volume of placebo (PLA; only excipient). Vials were identical for CAB and PLA and labeled with consecutive numbers by the manufacturer. Cows that were eligible for the study (i.e., milk yield $>16 \mathrm{~kg} / \mathrm{d}$; dry period $>35 \mathrm{~d}$ ) were assigned consecutive numbers in the order they were enrolled in the study. For each farm, computer-generated randomization lists were provided to match vial numbers and cow numbers. Investigators and farm personnel had no knowledge about the content of each vial. All investigators (i.e., 8 veterinarians) were trained in carrying out the necessary measurements before the initiation of the study. Based on a written standard operating procedure, all investigators conducted several trial measurements and, when disagreement occurred, they reviewed the methods until agreement was reached. The standard operating procedure included pictures and schematics of all necessary procedures and was available during the whole study and attached to each study protocol.

\section{Udder Characteristics}

Measurements were carried out repeatedly during 3 phases. To generate baseline values, measurements were taken before and after milking once $4 \mathrm{~d}$ before dry off $(d-4)$. After dry off, measurements were conducted 3 times during the initial engorgement phase (i.e., $\mathrm{d} 1$, 2, and 3), when milk accumulated in the udder (Hurley, 1989; Oliver and Sordillo, 1989), and 3 times during the following regression phase (i.e., d 7, 10, and 14), when mammary gland secretion was significantly reduced (Wheelock et al., 1967; Oliver and Sordillo, 1989). Measurements on $\mathrm{d}-4$ before milking and measurements after dry off were carried out in the barn while cows were fixated in head locks or their stalls (i.e., ropes were fixed between stall partitions to prevent cows from leaving their stalls), respectively. Whereas measurements on $\mathrm{d}-4$ before milking had to be conducted less than $2 \mathrm{~h}$ before milking, measurements after dry off were carried out at the same time every day and approximately at the time cows were milked and dried off on d 0. Measurements after milking were taken immediately after removal of the milking clusters in the milking parlor.

Udder pressure was measured using a hand-held dynamometer (Penefel DFT 14, Agro Technologies, Forges les Eaux, France) as previously validated (Bertulat et al., 2012). In brief, the dynamometer was equipped with a 15 -mm measuring tip and a plastic plate $(70 \times$ $100 \mathrm{~mm}$ ), $20 \mathrm{~mm}$ behind and parallel to the surface of the measuring tip defining the penetration depth. The dynamometer measures the maximum weight bearing on the tip in kilograms. The measuring range is 0.05 to $14 \mathrm{~kg}$ with a precision of $\pm 0.04 \mathrm{~kg}$, according to the manufacturer. The unit was programmed to a threshold of $0.3 \mathrm{~kg}$ and to display mean and coefficient of variation of 5 consecutive measurements. Mean values with a coefficient of variation exceeding $10 \%$ were discarded and the measurement repeated. All investigators were trained in handling the dynamometer according to a standard operating procedure based on previous recommendations (Bertulat et al., 2012). Initial measurements (i.e., $\mathrm{d}-4$ ) were conducted once $1 \pm 0.5 \mathrm{~h}$ before milking and a second time in the milking parlor directly after milking to obtain 2 baseline pressure values. After dry off, all measurements were carried out at approximately (i.e., $\pm 1 \mathrm{~h}$ ) the same time every day.

In accordance with a previous study (Rees et al., 2014) that discovered only a low relationship between udder pressure measurements by dynamometer and manual palpation of udder firmness, udder pressure measurements were complemented by manual estimation of udder firmness utilizing a 4-point scale as described by Rees et al. (2014). To determine the udder engorgement and a subsequent decrease in udder size with as little bias as possible, distances between the front, hind, left, and right teats were determined utilizing a sliding caliper. The opening of the teat canal was used as measuring point. Values were recorded with an accuracy of $\pm 0.5 \mathrm{~cm}$. The sum of the 4 measured teat distances within an udder was defined as the total teat distance (TTD; Bertulat et al., 2012).

Milk leakage was specified as milk dripping from 1 or more teats at the time of examination. Udder pain was defined as avoidance behavior (e.g., flinching, vocalizing, leg raising, or tail wagging), manifesting during the daily udder palpations and firmness estimations (Kirscher et al., 2012). Cows were considered to have udder pain if they showed at least 1 of the behaviors mentioned while the investigator palpated the udder. The absence or occurrence of milk leakage and signs of udder pain were recorded as a binary variable by the investigators each day at the same time.

\section{Statistical Analysis}

Data were entered and managed utilizing Capture System (version 5.5, Clinsight, Poitiers, France). After freezing of the database, data were exported to Excel spreadsheets (version 2013, Microsoft, Redmond, WA) for further processing. Statistical analyses were performed with IBM SPSS Statistics for Windows (version 23.0, IBM Deutschland GmbH, Ehningen, Germany). The significance level was set at $P \leq 0.05$ and trends were discussed at $0.05<P \leq 0.10$.

Normality of distributions of continuous parameters (i.e., udder pressure, TTD) was assessed by plotting and visually examining the data, calculating a Q-Q 
plot, and using the Shapiro-Wilk test. Equality of variances was determined using Levene's test. Homogeneity of the proportion of parity (i.e., 1st, 2nd, 3rd, or higher lactation) and treatment group (i.e., CAB and PLA) within each farm was evaluated with $\chi^{2}$ test. Comparability of $\mathrm{CAB}$ and PLA cows within each farm before dry off considering milk yield (i.e., at the time of dry off and 305-d lactation) and pretreatment baseline values (i.e., d -4) was tested utilizing student's t-test (i.e., milk yield, udder pressure, udder perimeter) or $\chi^{2}$ test (i.e., udder firmness, milk leakage, udder pain).

Further analyses on continuous variables (i.e., udder pressure, TTD) were carried out applying a generalized linear mixed model. All mixed models were built according to the model-building strategies (Dohoo et al., 2009). In brief, all independent parameters were tested with Spearman's correlation (i.e., ordinal parameter) or Pearson correlation (i.e., scaled parameter) for colinearity and analyzed in a univariate model. If 2 parameters showed a high, significant correlation, only the 1 resulting in the univariate model with the smallest $P$-value was used in the final model. Furthermore, only parameters resulting in univariate models with $P \leq 0.2$ were included in the final mixed model. This final model was built in a conditional backward stepwise manner. Days after dry off was included as a repeated factor and cow within farm as random effect. Interactions were tested for all relevant parameters. The covariate structure was chosen based on the lowest Akaike information criterion value. Post hoc comparison was carried out applying LSD test.

Analyses considering udder firmness, milk leakage, and udder pain were done utilizing a generalized linear mixed model for ordinal and binary variables, respectively. The models were built equivalent to the linear mixed model ANOVA described above. Cow within farm and days after dry off were included as random and repeated effect, respectively. Interactions were tested for all relevant parameters again. Odds ratios and confidence intervals were calculated for all significant parameters.

The following independent parameters were considered as predictors in the models: treatment group, days after dry off, parity, DIM at the time of dry off, 305d lactation, milk yield at dry off, parity, breed, and season. Udder pressure was furthermore included as a covariate in the models calculating the effect on TTD, milk leakage, and udder pain. The occurrence of milk leakage before dry off was included as a factor in the model on milk leakage.

Because this study was the first of this kind, reported data for a preceding sample size calculation were not available in the literature. Based on unpublished data provided by the manufacturer (Ceva Santé Animale), a prevalence of $19 \%$ milk leakage on the day after dry off in PLA cows and a 50\% reduction in the CAB group were assumed. To achieve $80 \%$ power with a 2 -sided $\alpha$ level of 5\%, 114 cows per groups were assumed to be required for the study. Because this was a multicentric study, the number of animals enrolled per group was furthermore increased by $15 \%$ (i.e., 131 animals per group), as suggested by Dohoo et al. (2009).

\section{RESULTS}

Two hundred sixty-three cows (PLA $\mathrm{n}=133$; CAB $\mathrm{n}=130)$ were enrolled in the study. Fifteen cows had to be excluded during the study period due to other disease [i.e., mastitis $(\mathrm{n}=4)$, premature calving or abortion $(\mathrm{n}=2)$ ] or deviations from the trial protocol [e.g., treatment more than $4 \mathrm{~h}$ after last milking $(\mathrm{n}=6)$, no follow-up between $\mathrm{d} 7$ and $14(\mathrm{n}=3)]$. Furthermore, 4 farms (i.e., 8, 11, 15, and 16; Table 1) with 14 cows were excluded for their low number of cows eligible for final analysis.

Two hundred thirty-four cows were used for the final analyses. Average milk yield $7 \mathrm{~d}$ before dry off and 305-d lactation were $20.1 \pm 3.8$ and $9,049 \pm 2,033 \mathrm{~kg}$ in $\mathrm{CAB}$ and $20.3 \pm 3.5$ and $9,197 \pm 1,813 \mathrm{~kg}$ in PLA cows, respectively. Milk yield before dry off and 305-d lactation did not differ between treatment groups on any of the farms $(P>0.05)$.

The statistical power for the repeated measurement of udder pressure and milk leakage after dry off in both treatment groups was 0.85 and $0.989(\mathrm{f}=0.16)$, respectively. The probability of error in accepting the null hypothesis was 15 and $0.11 \%$ for analysis concerning udder pressure and milk leakage, respectively. For both calculations, the power of analysis is within the limits set by Cohen (1988) and Prajapati et al. (2010). The error in the analysis due to sample size is acceptable.

\section{Udder Pressure and Firmness}

Udder pressure baseline values before and after milking were similar $(P>0.05)$ in $\mathrm{CAB}$ (mean $\pm \mathrm{SD}$; before milking $=1.03 \pm 0.42 \mathrm{~kg}$; after milking $=0.54 \pm 0.15$ $\mathrm{kg}$ ) and PLA cows (before milking $=1.03 \pm 0.43 \mathrm{~kg}$; after milking $=0.54 \pm 0.15 \mathrm{~kg})$. Udder pressure after dry off was significantly reduced by $\mathrm{CAB}$ treatment $(P=$ 0.001; Table 2) and we noted 2 interactions [i.e., treatment group $\times$ days relative to dry off $(P<0.001$; Table $3)$ and treatment group $\times$ parity $(P=0.036$; Figure $1)$ ]. Whereas udder pressure in PLA cows was highest on $\mathrm{d} 1$ and decreased afterward, CAB-treated cows had a slower increase of udder pressure after dry off with a 
Table 2. Final generalized linear model showing the association of significant variables $(P \leq 0.05)$ and udder pressure in 234 dairy cows

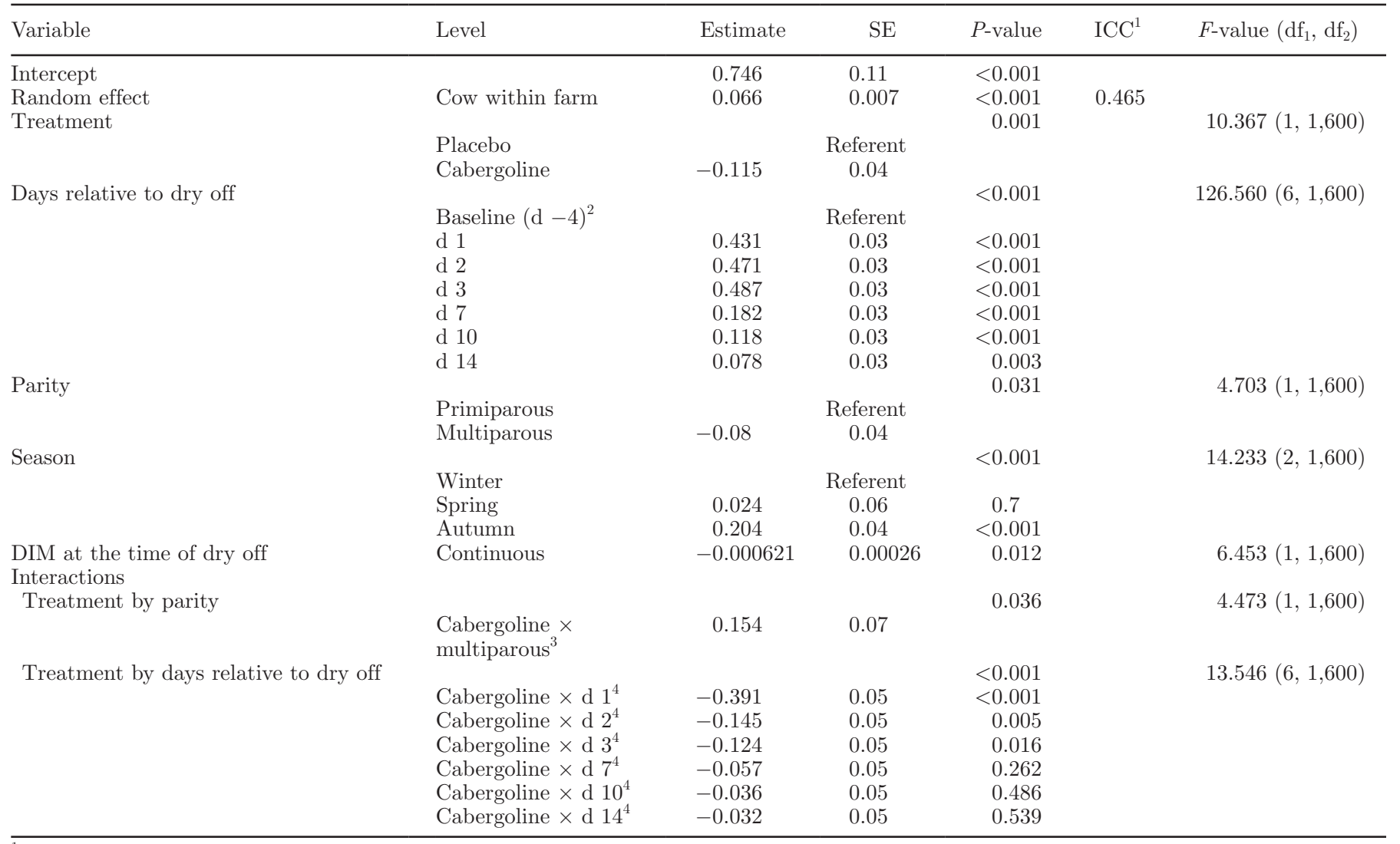

${ }^{1}$ Intraclass correlation coefficient; shows the amount of clustering by cow within farm.

${ }^{2}$ After milking.

${ }^{3}$ Placebo treatment and primiparous were used as reference categories and set to 0 .

${ }^{4}$ Placebo treatment and baseline $(\mathrm{d}-4)$ were used as reference categories and set to 0 .

peak on d 2 (Table 3). From d 7 to 14, udder pressure did not change within both groups $(P>0.05)$. Whereas all pressure values measured in $\mathrm{CAB}$ cows after dry off were lower than values before milking on $\mathrm{d}-4(P<$ 0.05), udder pressures in PLA cows on $d 1$ were higher than corresponding baseline values before milking on $\mathrm{d}$ $-4(P=0.023)$. Udder pressure values between groups differed on $\mathrm{d} 1(P<0.001), 2(P=0.002)$, and $3(P=$ 0.009 ), but no differences were found between $\mathrm{d} 7$ and $14(P>0.05)$. Within parity groups, CAB significantly reduced udder pressure in primiparous $(P=0.001)$, but not in multiparous cows $(P=0.322$; Figure 1$)$.

Udder firmness baseline values estimated by manual palpation did not differ between CAB and PLA cows before or after milking $(P>0.05)$. On the first day after dry off, average firmness scores were $2.64 \pm 0.06$ and $2.06 \pm 0.06$ in PLA and CAB cows, respectively $(P<0.001)$. Udder firmness was furthermore affected by days relative to dry off $\left(F=124.3 ; \mathrm{df}_{1}=6 ; \mathrm{df}_{2}=\right.$ $1,611 ; P<0.001)$ and an interaction between treatment group and days relative to dry off $\left(F=6.1 ; \mathrm{df}_{1}=6\right.$; $\left.\mathrm{df}_{2}=1,611 ; P=0.001\right)$. Considering this interaction, udder firmness in CAB cows was lower during the engorgement phase on d 1,2, and 3 compared with PLA cows $(P<0.05$; Figure 2$)$, but we found no difference on $\mathrm{d} 7$ or afterward $(P>0.05)$. Udder firmness was furthermore affected by season $\left(F=34.7 ; \mathrm{df}_{1}=2 ; \mathrm{df}_{2}\right.$ $=1,611 ; P<0.001)$ and milk yield before dry off $(F$ $\left.=38.8 ; \mathrm{df}_{1}=1 ; \mathrm{df}_{2}=1,611 ; P<0.001\right)$, with higher firmness scores in cows with higher milk yield.

\section{TTD}

Baseline TTD did not differ between CAB and PLA cows before or after milking $(P>0.05)$. After dry off, TTD increased $(P<0.05)$, peaking on $\mathrm{d} 2$ and then decreasing until d $14(P<0.001$; Figure 3$)$. Baseline values, however, were not attained until the end of the study period, $14 \mathrm{~d}$ after dry off $(P<0.001)$. Within days, TTD was significantly lower in CAB cows on $\mathrm{d} 1$ $(P=0.001)$ and $2(P=0.064)$, but not afterward (Figure 3$)$. Total teat distance was higher in multiparous 
$(42.8 \pm 1.0 \mathrm{~cm})$ compared with primiparous cows $(39.2$ $\left.\pm 1.1 \mathrm{~cm} ; F=6.6 ; \mathrm{df}_{1}=6 ; \mathrm{df}_{2}=1,599 ; P=0.011\right)$ and in cows with higher $305-\mathrm{d}$ lactation yield $\left(F=6.8 ; \mathrm{df}_{1}\right.$ $\left.=1 ; \mathrm{df}_{2}=1,599 ; P=0.009\right)$. Furthermore, values were higher if measured in winter $(45.1 \pm 1.0 \mathrm{~cm} ; P<0.05)$, but did not differ between spring $(38.3 \pm 1.9 \mathrm{~cm})$ and autumn $(39.7 \pm 0.9 \mathrm{~cm} ; P=0.510)$.

\section{Milk Leakage}

Before dry off, milk leakage was observed in 8 out of $115 \mathrm{CAB}$ and 3 out of 119 PLA cows $(P=0.841)$. After dry off, milk leakage occurred in 21.0 and $11.3 \%$ of PLA and CAB cows, respectively $(P<0.001)$; cows with milk leakage before dry off were more likely to leak after dry off as well $(P<0.001)$. Ten PLA (i.e., $8.4 \%$ ) and $3 \mathrm{CAB}$ (i.e., $2.6 \%$ ) cows had milk leakage on more than $1 \mathrm{~d}$ after dry off. Overall, PLA cows were 12.5 times as likely to show milk leakage compared with CAB-treated cows $(\mathrm{CI}=2.51-62.50 ; P$ $=0.002)$. The probability of the occurrence of milk leakage after dry off was furthermore affected by the number of days after dry off $(P=0.001)$, udder pressure $(P<0.001)$, and an interaction between treatment group and udder pressure $(P=0.007)$. Whereas cows with high udder pressure were more likely to show milk leakage compared with cows with low pressure values, the prevalence of milk leakage was highest on $\mathrm{d} 1$ after dry off and decreased afterward (Table 4). Considering the interaction between udder pressure and treatment, lower pressure values were found in PLA cows with milk leakage than in CAB cows that leaked milk $(P<$ 0.001). In cows without milk leakage, however, udder pressure was lower in $\mathrm{CAB}$ compared with PLA cows $(P=0.035)$.

\section{Udder Pain}

Before dry off, udder pain was not observed in CAB or PLA cows. Within the engorgement phase between $\mathrm{d}$ 1 and 3 after dry off, signs of udder pain were noted 12 times in $8 \mathrm{CAB}$ (3.5\% of measurements; $7.0 \%$ of cows) and 32 times in 19 PLA cows (9.0\% of measurements; $16.0 \%$ of cows). Days after dry off was not included in the final multivariate model, as we found no relationship between the number of days after dry off and the occurrence of udder pain in the univariate model $(P=$ 0.684). Considering the multivariate model, PLA cows were 2.79 times $\left(F=12.2 ; \mathrm{df}_{1}=1 ; \mathrm{df}_{2}=698 ; \mathrm{CI}=1.57\right.$ $-4.97 ; P=0.001)$ as likely to show signs of udder pain compared with cows treated with CAB. Interestingly, primiparous cows were 2.45 times more likely to show signs of udder pain than multiparous cows $\left(F=9.1 ; \mathrm{df}_{1}\right.$ $\left.=1 ; \mathrm{df}_{2}=698 ; \mathrm{CI}=1.38-4.48 ; P=0.003\right)$. The occurrence of udder pain was furthermore associated with higher udder pressure values $\left(F=63.1 ; \mathrm{df}_{1}=1 ; \mathrm{df}_{2}=\right.$ 698 ; odds ratio $=11.75 ; \mathrm{CI}=6.39-21.61 ; P<0.001)$.

\section{DISCUSSION}

Considering intense genetic selection and continuously increasing milk production (Lucy, 2001; Thornton, 2010; Zobel et al., 2015), new and science-based methods are necessary to ensure udder health and animal welfare during dry off and a successful transition to the new lactation period. Previous studies have investigated effects of long-term quinagolide treatment, another prolactin-release inhibitor on histological and biochemical processes (Ollier et al., 2013, 2014, 2015), but are not comparable to our study design. When quinagolide was administered once or twice daily, start-

Table 3. Daily udder pressure (LSM \pm SE; $\mathrm{kg}$ ) before (i.e., after milking) and after dry off in cabergoline- (n $=115)$ and placebo-treated $(\mathrm{n}=119)$ cows; interaction between treatment group and days relative to dry off

\begin{tabular}{lccr}
\hline & \multicolumn{2}{c}{ Treatment group } & \\
\cline { 2 - 3 } Day relative to dry off & Cabergoline & Placebo & P-value \\
\hline Baseline $^{2}$ & $0.51 \pm 0.014^{\mathrm{a}}$ & $0.52 \pm 0.015^{\mathrm{a}}$ & 0.909 \\
d 1 & $0.75 \pm 0.032^{\mathrm{b}}$ & $1.14 \pm 0.056^{\mathrm{b}}$ & $<0.001$ \\
d 2 & $0.91 \pm 0.041^{\mathrm{c}}$ & $1.06 \pm 0.046^{\mathrm{c}}$ & 0.002 \\
d 3 & $0.94 \pm 0.048^{\mathrm{c}}$ & $1.07 \pm 0.057^{\mathrm{bc}}$ & 0.009 \\
d 7 & $0.67 \pm 0.027^{\mathrm{d}}$ & $0.73 \pm 0.033^{\mathrm{d}}$ & 0.203 \\
d 10 & $0.61 \pm 0.026^{\mathrm{de}}$ & $0.65 \pm 0.028^{\mathrm{de}}$ & 0.456 \\
d 14 & $0.58 \pm 0.027^{\mathrm{ae}}$ & $0.61 \pm 0.027^{\mathrm{e}}$ & \\
$P$-value & $<0.001$ & \\
${ }^{\mathrm{a}-\mathrm{e}}$ Values with same superscripts within column do not differ significantly $(P>0.05) ;$ all other values differ \\
significantly $(P<0.05)$. & & \\
${ }^{1}$ Within days between groups effect. & & \\
${ }^{2}$ After milking. & & \\
${ }^{3}$ Within groups between days effect. & &
\end{tabular}



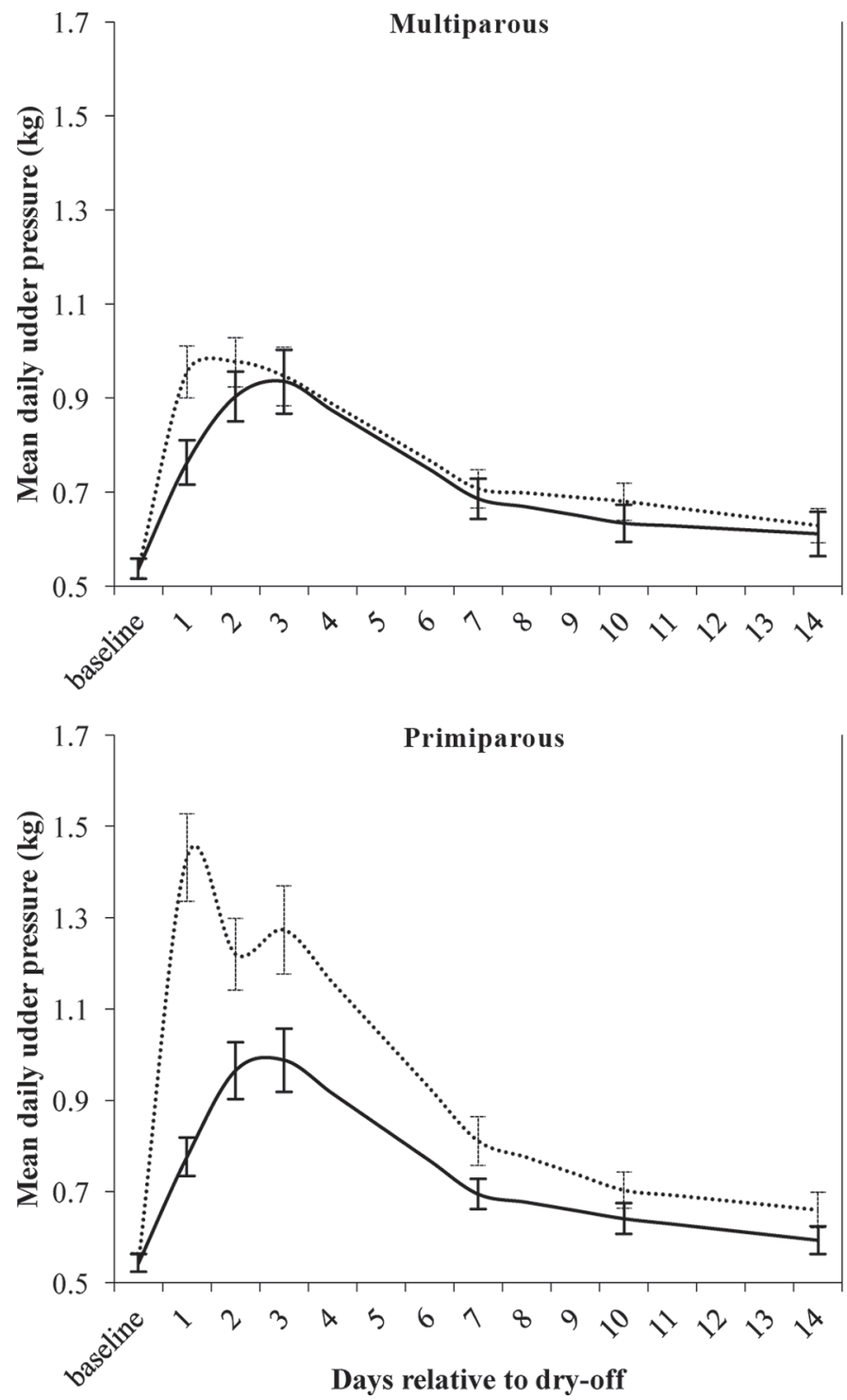

Figure 1. Daily udder pressure (LSM $\pm \mathrm{SE}$; $\mathrm{kg}$ ) before (i.e., after milking) and after dry off in cabergoline- (solid line) and placebotreated (dotted line) cows considering parity (primiparous $\mathrm{n}=111$; multiparous $\mathrm{n}=123)$.

ing 3 to $4 \mathrm{~d}$ before dry off, milk production was reduced by 36 to $45 \%$ within a single day (Ollier et al., 2013, 2014, 2015). Those authors hypothesized that quinagolide might inhibit milk production by its action on prolactin secretion. Results presented by Boutinaud et al. (2016) indicate a similar effect of $\mathrm{CAB}$ on prolactin secretion, causing reduced milk secretion after dry off.

According to previous studies (Oliver and Sordillo, 1989; Pezeshki et al., 2010; Leitner et al., 2011; Silanikove et al., 2013), milk yield before dry off affects mammary gland involution and natural defense systems during the dry period. A reduced milk secretion in $\mathrm{CAB}$ cows might support a faster activation of the immune system, as suggested by Boutinaud et al. (2016), and a more effective antibacterial response, similar to lowyielding cows (i.e., $<14 \mathrm{~kg}$ of milk) at dry off (Silanikove et al., 2013). A positive effect of a prolactin-release inhibitor on new IMI was furthermore demonstrated by Ollier et al. (2015), who found a lower percentage of quarters infected with Streptococcus agalactiae after artificial challenge in cows treated with quinagolide. Those authors hypothesized that the reduced milk secretion in quinagolide-treated cows might also hasten the formation of the bacteria-protective keratin plug. Whether a similar result can be achieved through a single $\mathrm{CAB}$ injection in a commercial dairy farm environment with naturally occurring infections remains to be seen.

Nevertheless, considering previous research, we assumed that $\mathrm{CAB}$ might reduce the milk secretion after dry off and that the latter would lead to lower udder pressure values (Tucker et al., 1961; Graf and Lawson, 1968; Bertulat et al., 2012). A previous study showed that udder pressure after dry off in dairy cows is affected by milk yield before dry off (Bertulat et al., 2013). In our study, pressure values measured in PLA cows within the first week after dry off were similar to those measured by Bertulat et al. (2013) in cows with more than $15 \mathrm{~kg}$ of milk/d. Pressure values in $\mathrm{CAB}$ cows, however, resembled those from low-yielding cows with $<15 \mathrm{~kg}$ of milk/d at the time of dry off. This observation supports the assumption that $\mathrm{CAB}$ reduces milk secretion after dry off.

Interestingly, we were able to evaluate an interaction between treatment and days after dry off in the model on udder pressure, udder firmness, and TTD. For example, an effect of $\mathrm{CAB}$ on udder pressure was only significant on d 1 and 2, and there was a tendency on d 3 but not afterward. Differences between treatment groups in the model on udder firmness and TTD were found until d 3 and 2 (tendency on d 3), respectively. Ollier et al. (2013) showed that prolactin concentrations in cows decreased immediately after quinagolide injection, but reached previous concentrations within $1 \mathrm{~d}$ after last injection. Whereas the blood elimination half-life of quinagolide is about $20 \mathrm{~h}$ in humans (Lacasse et al., 2012), the CAB half-life varies between 17 and $40 \mathrm{~h}$ (Committee for Medicinal Products for Veterinary Use, 2014). Studies comparing the efficacy of quinagolide and $\mathrm{CAB}$ in treating hyperprolactinemia and prolactinomas in humans showed that $\mathrm{CAB}$ has higher cure rates and allows longer intervals between treatments (Giusti et al., 1994; Di Sarno et al., 2000; De Luis et al., 2000). Therefore, it seems likely that the inhibitory effect of $\mathrm{CAB}$ on prolactin secretion in dairy cows is stronger, but follows a similar but delayed kinetic, as shown in the quinagolide studies. Because 
of a prolonged half-life of $\mathrm{CAB}$, we only used a single injection, whereas in quinagolide studies cows were injected repeatedly once or even twice daily (Ollier et al., 2013, 2014). Therefore, it seems plausible that effects of CAB treatment cannot be found 7 to $14 \mathrm{~d}$ after dry off. This assumption is supported by results indicating that a single $\mathrm{CAB}$ injection is able to decrease blood prolactin concentrations for up to $8 \mathrm{~d}$ after injection (Boutinaud et al., 2016). Further studies are necessary to clarify the biochemical mode of action of $\mathrm{CAB}$ in dairy cows and to evaluate prolactin as well as $\mathrm{CAB}$ concentrations after CAB treatment.

Although the interaction between treatment and days after dry off was more or less expected due to results already published on quinagolide, the second interaction between treatment and parity found in the model on udder pressure was a surprise. Cabergoline seemed to be more effective in reducing udder pressure in younger cows compared with older cows. A previous study on stress related to an abrupt dry off (Bertulat et al., 2013) did not find an effect of parity on udder pressure. Chapinal et al. (2014) evaluated changes in lying behavior as an indicator for udder discomfort in primi- and multiparous cows after abrupt cessation of milking. Only in primiparous cows were higher milk yield before dry off and reduced lying behavior after dry off related. This effect on primiparous but not multiparous cows was partly explained by age-related differences in the mammary gland tissue (Davis et al., 1999; Klaas et al., 2004). It remains unclear, however, why udder pressure after dry off was more effectively reduced in primiparous compared with multiparous cows. We speculated that primiparous cows might be more susceptible for prolactin inhibition, perhaps due to different persistency of milk production (Jingar et al., 2014).

Besides the interactions treatment $x$ days relative to dry off and treatment $\times$ parity, udder pressure was affected by season. Season also remained a factor in the models on udder firmness and TTD. Whereas udder pressure and firmness values were lowest in winter, TTD was highest. Milk yield at the time of dry off was one of the most important factors affecting udder pressure values (Bertulat et al., 2013); however, it did

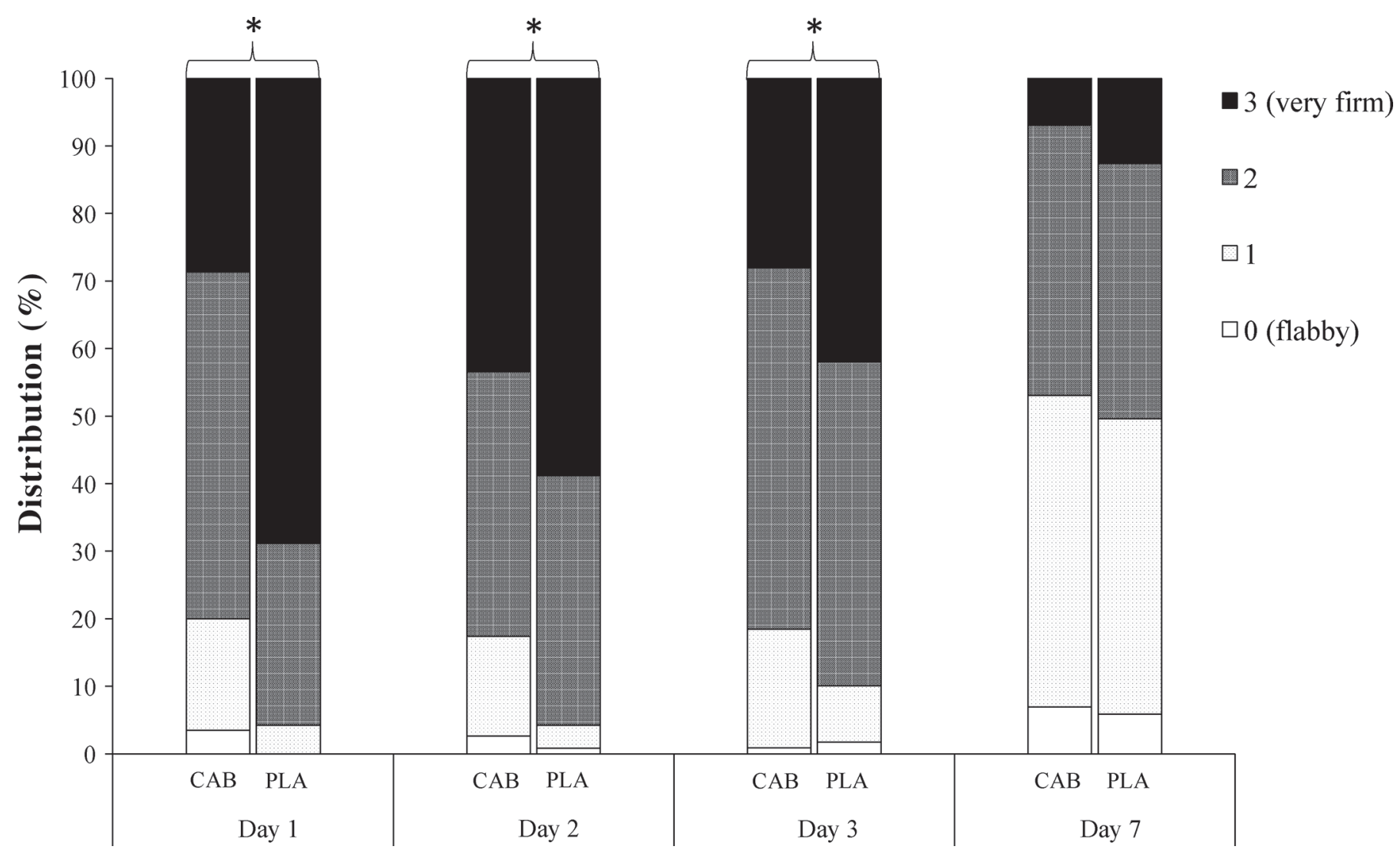

Figure 2. Distribution of udder-firmness scores (i.e., 0 to 3; flabby to very firm) by percentage after dry off in cows treated with cabergoline $(\mathrm{CAB} ; \mathrm{n}=115)$ and placebo $(\mathrm{PLA} ; \mathrm{n}=119)$. An asterisk $\left(^{*}\right)$ represents udder firmness values differ between treatment groups within days $(P$ $<0.05)$. 


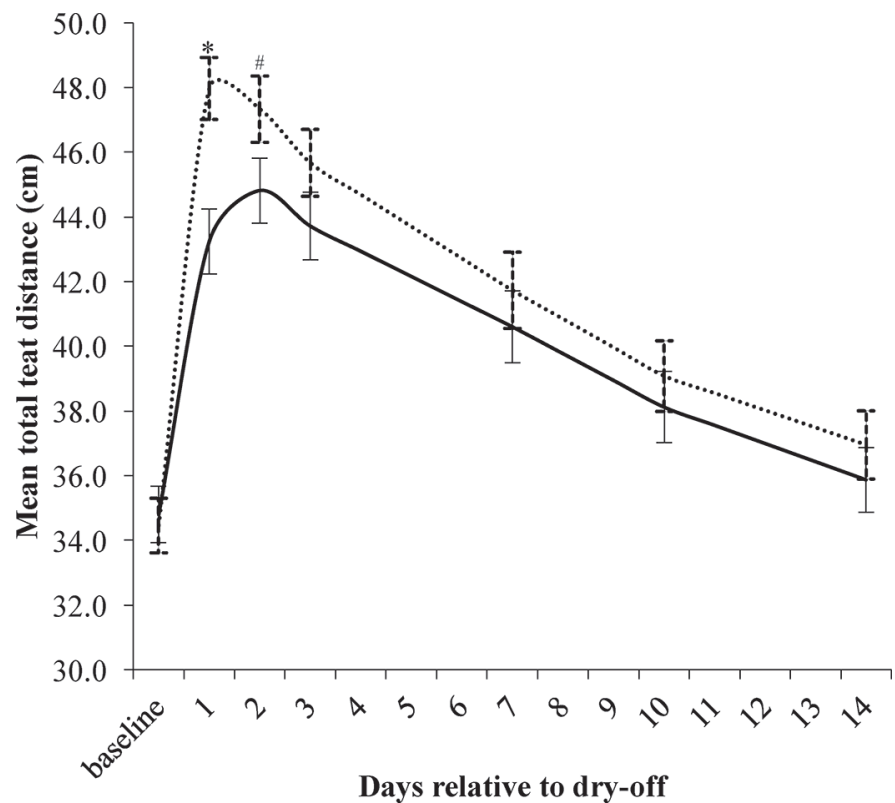

Figure 3. Total teat distance (i.e., sum of teat distances; LSM \pm $\mathrm{SE} ; \mathrm{cm})$ before and after dry off in cabergoline- (solid line; $\mathrm{n}=115)$ and placebo-treated (dotted line; $\mathrm{n}=119$ ) cows. An asterisk $\left(^{*}\right.$ ) represents a difference within days between groups for $P<0.05$; a pound sign (\#) represents a difference within days between groups for $P<$ 0.01 .

not differ between cows dried off during the varying seasons (i.e., fall $=20.0 \pm 3.5$; winter $=20.5 \pm 3.9$; spring $=20.2 \pm 2.8 ; P=0.523)$. Again, these findings elude a substantiated explanation. To our knowledge, similar results have not been published. We speculated that, due to lower temperatures in winter, udder tissue contracts to reduce the surface prone to temperature loss and prevent tissue damage and frost bite. Such a contraction, however, would be associated with higher udder pressure, increased udder firmness, and lower TTD, and therefore does not explain the findings in our study. A measurement error seems unlikely as well, for this seasonal effect was found in 3 outcome variables with no difference between values measured in autumn and spring, but variations in winter. It might be interesting to further research this phenomenon to investigate the effect of ambient temperature on udder characteristics.

The intraclass correlation coefficient calculated for the model on udder pressure illustrated the correlation between udder pressure values measured within a cow within farm over several days after dry off. An intraclass correlation coefficient of 0.465 is conserved as a fair correlation (Cicchetti, 1994). As demonstrated in a previous paper (Bertulat et al., 2013), cows with high udder pressure values on d 1 or 2 after dry off had higher values on the following days as well. Therefore, the inclusion of cow within farm as a random effect in the model is justified.

Same as udder pressure, udder firmness, and TTD, the probability of milk leakage was highest on the first day after dry off. This finding is in agreement with previous studies, which demonstrated a positive relationship between milk leakage and udder pressure both during lactation and after dry off (Rovai et al., 2007; Bertulat et al., 2013); furthermore, we found an interaction between treatment and udder pressure. In cows without milk leakage, udder pressure was lower if cows were treated with $\mathrm{CAB}$, but it was higher in $\mathrm{CAB}$ cows with milk leakage. Therefore, it might be speculated that in $\mathrm{CAB}$ cows, higher pressure values are necessary to trigger milk leakage. We hypothesized that CAB-

Table 4. Final generalized linear model showing the association of significant variables $(P \leq 0.05)$ and milk leakage in 234 dairy cows

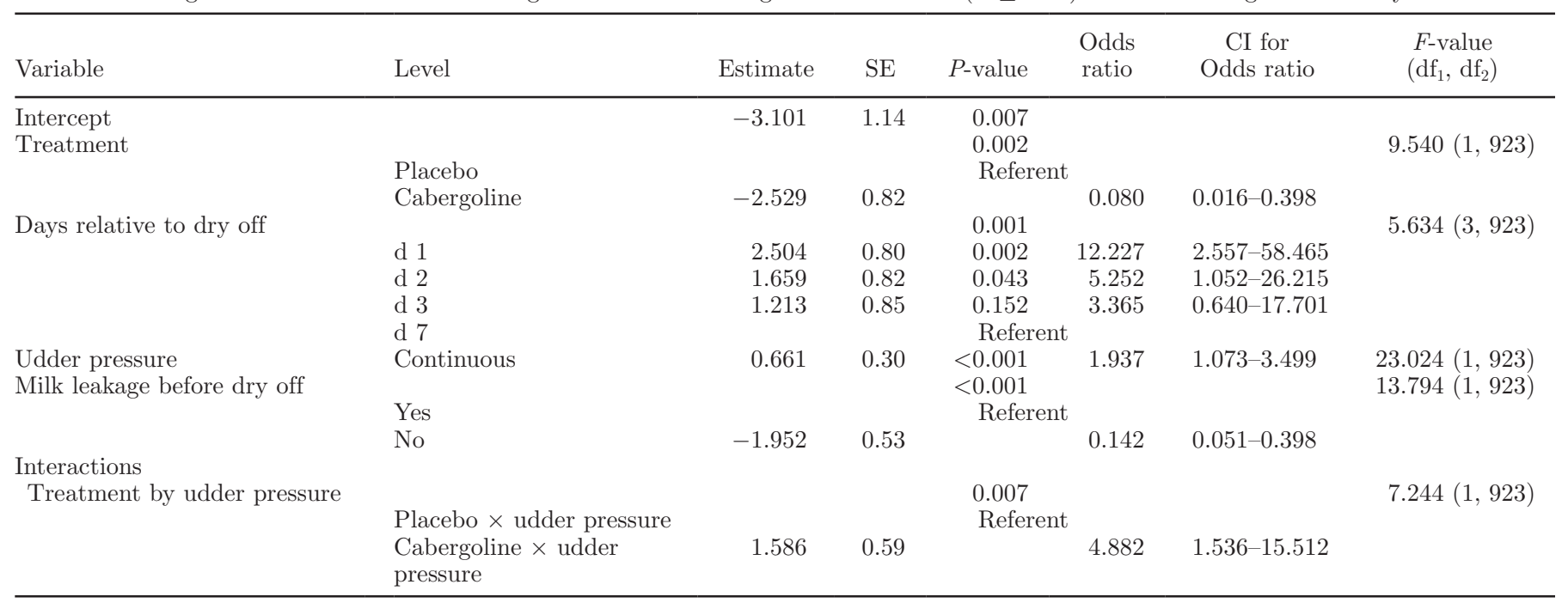


treated cows had lower udder pressure after dry off and, therefore, would also be less likely to show milk leakage (Rovai et al., 2007). But based on our results, CAB does not only affect udder pressure, but seems to have a further positive effect on the prevention of milk leakage by raising the pressure threshold that is necessary for milk leakage to occur. An increased rate of teat canal closure and a fastened teat-canal keratin plug formation might be the reason. Dingwell et al. (2004) investigated the association of cow- and quarter-level factors with new IMI and were able to demonstrate that the administration of antibiotic dry cow treatment increased the rate of closure. A reduction of milk production caused by $\mathrm{CAB}$ treatment, further promotes teat-canal keratin plug formation and a rapid closure of the teat canal (Dingwell et al., 2004; Odensten et al., 2007; Zobel et al., 2013). This finding is highly important, as it is well known that milk leakage is a major risk factor for IMI after dry off (Schukken et al., 1993; Waage et al., 1998; Pezeshki et al., 2010). Although Bach et al. (2015) presented similar results on the reduction of milk leakage caused by $\mathrm{CAB}$ treatment, further studies are necessary to confirm the assumption that $\mathrm{CAB}$ might reduce IMI during the dry period as well.

The occurrence of udder pain was facilitated by high pressure values and was more likely in cows treated with PLA and in primiparous cows. The effect of $\mathrm{CAB}$ to reduce signs of udder pain after dry off might be a side-effect of decreased udder pressure and reduced milk secretion in CAB-treated cows. It has been shown that an abrupt dry off in high-yielding cows provokes distress responses, which were associated with neutrophilia in milk (Silanikove et al., 2013). As CAB is a prolactininhibitor that reduces milk secretion and lowers milk production, it seems plausible that distress-associated immune responses in our study triggered by high udder pressure were reduced as well. This assumption is substantiated by previous results on stress hormone levels after dry off (Bertulat et al., 2013). Stress hormone concentrations (e.g., cortisol and its metabolites) that have been repeatedly used as indicators of pain and discomfort (Anil et al., 2002; Rutherford, 2002) barely increased in low-yielding (i.e., $<15 \mathrm{~kg}$ ) cows after dry off. It remains unclear, however, why primiparous cows were more likely to show signs of udder pain after dry off compared with multiparous cows. A kind of habituation might occur in multiparous cows, as they experienced the dry off processes and the related discomfort in their last lactation. Fernandez et al. (1995) hypothesized that multiparous compared with primiparous dairy ewes had lower pressure on the teat when the udder is in repletion due to changes in the udder morphology (i.e., reduced teat length and width). Albeit not evaluated, similar changes in the udder morphology might apply for multiparous cows as well. Nevertheless, the results on udder pain, albeit interesting, need to be interpreted carefully. Udder pain was evaluated by different investigators as a behavioral reaction to udder palpation. Tuyttens et al. (2014) showed that observer bias could influence scores of animal behavior and welfare. We tried to minimize potential bias by evaluating udder pain as a binary variable instead of a pain score. Furthermore, all investigators were provided with a standard operation procedure before the study that gave clear descriptions as to which behaviors should be considered indicative of pain. The estimation of udder pain could have been optimized by utilizing an algometer, as described by Fitzpatrick et al. (2013). Albeit not validated for this application, those authors used the device to apply pressure to mastitic quarters and measured the force necessary to achieve avoidance behavior (i.e., movement away from the pressure). This method has merit for it facilitates a more differentiated evaluation of pain than a mere palpation.

\section{CONCLUSIONS}

Our data provide evidence that a single injection of $\mathrm{CAB}$ is able to mitigate negative side effects of the dry off procedure in high-yielding dairy cows and might be considered a dry off facilitator. Udder pressure, milk leakage, and signs of udder pain were significantly reduced during the initial engorgement phase after dry off, without interference of the later regression phase. Whereas younger cows seem to profit from reduced udder pressure and less signs of udder pain. An application of $\mathrm{CAB}$ in the field is feasible as the effects were prevalent after a single treatment at dry off. Whereas in our study the threshold for high milk yield was set at $16 \mathrm{~kg}$ and the milk yield before dry off in our study population was similar in most cows, we are aware that, particularly in North America, milk yield at dry off often exceeds $30 \mathrm{~kg}$ and more. Further research is warranted to investigate the effect of $\mathrm{CAB}$ in cows with higher milk yield and to evaluate if efficacy of CAB is related to milk yield before dry off. Although relationships between udder pressure and stress levels as well as between milk leakage and IMI are known, further studies should be conducted to demonstrate if a CAB treatment at dry off can help to reduce new IMI rates and improve animal welfare after dry off. Whereas the sample size in our study was sufficient to evaluate the effect of $\mathrm{CAB}$ on udder pressure, milk leakage, and udder pain after dry off, a large-scale, controlled, randomized trial would be needed to determine any health effects or potential negative side effects of CAB. 


\section{ACKNOWLEDGMENTS}

The authors thank the participating veterinarians and the dairy farms for their superb cooperation. In particular, we acknowledge the staff of the Centre d'Elevage Lucien Biset, Poisy, France, especially Adeline Gaillot and the Institute for Veterinary Medical Research, Budapest, Hungary, and its director Tibor Magyar. This study was supported by CEVA Santé Animale (Libourne, France). We wish to extend our particular thanks to Audrey Deflandre (Ceva Santé Animale).

\section{REFERENCES}

Andersen, J. B., T. G. Madsen, T. Larsen, K. L. Ingvartsen, and M. O. Nielsen. 2005. The effects of dry period versus continuous lactation on metabolic status and performance in periparturient cows. J. Dairy Sci. 88:3530-3541.

Anil, S. S., L. Anil, and J. Deen. 2002. Challenges of pain assessment in domestic animals. J. Am. Vet. Med. Assoc. 220:313-319.

Annen, E. L., R. J. Collier, M. A. McGuire, and J. L. Vicini. 2004 Effects of dry period length on milk yield and mammary epithelial cells. J. Dairy Sci. 87(Supplement):E66-E76.

Arbeiter, K., W. Brass, R. Ballabio, and W. Jöchle. 1988. Treatment of pseudopregnancy in the bitch with cabergoline, an ergoline derivative. J. Small Anim. Pract. 29:781-788.

Arlt, S., A. Reinecke, M. Drillich, C. Fischer-Tenhagen, and W. Heuwieser. 2011. Mastectomy in goats with inappropriate lactation syndrome. Tierarztl. Prax. Ausg. G Grosstiere Nutztiere 39:27-32.

Bach, A., A. De-Prado, and A. Aris. 2015. Short communication: The effects of cabergoline administration at dry-off of lactating cows on udder engorgement, milk leakages, and lying behavior. J. Dairy Sci. 98:7097-7101.

Beever, D. E. 2006. The impact of controlled nutrition during the dry period on dairy cow health, fertility and performance. Anim. Reprod. Sci. 96:212-226.

Bertulat, S., C. Fischer-Tenhagen, and W. Heuwieser. 2015. A survey of drying-off practices on commercial dairy farms in northern Germany and a comparison to science-based recommendations. Vet. Rec. Open 2:e000068. https://doi.org/10.1136/vetreco-2014-000068.

Bertulat, S., C. Fischer-Tenhagen, V. Suthar, E. Möstl, N. Isaka, and W. Heuwieser. 2013. Measurement of fecal glucocorticoid metabolites and evaluation of udder characteristics to estimate stress after sudden dry-off in dairy cows with different milk yields. J. Dairy Sci. 96:3774-3787.

Bertulat, S., C. Fischer-Tenhagen, A. Werner, and W. Heuwieser. 2012. Technical note: Validating a dynamometer for noninvasive measuring of udder firmness in dairy cows. J. Dairy Sci. 95:6550-6556.

Boutinaud, M., N. Isaka, V. Lollivier, F. Dessauge, E. Gandemer, P. Lamberton, A. I. De Prado Taranilla, A. Deflandre, and L. M. Sordillo. 2016. Cabergoline inhibits prolactin secretion and accelerates involution in dairy cows after dry-off. J. Dairy Sci. 99:5707-5718.

Bushe, T., and S. P. Oliver. 1987. Natural protective factors in bovine mammary secretions following different methods of milk cessation. J. Dairy Sci. 70:696-704.

Chapinal, N., G. Zobel, K. Painter, and K. E. Leslie. 2014. Changes in lying behavior after abrupt cessation of milking and regrouping at dry-off in freestall-housed cows: A case study. J. Vet. Behav. Clin. Appl. Res. 9:364-369.

Cicchetti, D. V. 1994. Guidelines, criteria, and rules of thumb for evaluating normed and standardized assessment instruments in psychology. Psychol. Assess. 6:284-290.

Cohen, J. 1988. Statistical Power Analysis for the Behavioral Sciences. Second Edition. Taylor \& Francis, Hillsdale, NJ.

Committee for Medicinal Products for Veterinary Use. 2014. Cabergoline (bovine): European public maximum-residue-limit assessment report (EPMAR) - CVMP. EMA/CVMP/656490/2013. European Medicines Agency, London, UK.

Davis, S. R., V. C. Farr, and K. Stelwagen. 1999. Regulation of yield loss and milk composition during once-daily milking: A review. Livest. Prod. Sci. 59:77-94.

De Luis, D. A., A. Becerra, M. Lahera, J. I. Botella, M. A. Valero, and C. Varela. 2000. A randomized cross-over study comparing cabergoline and quinagolide in the treatment of hyperprolactinemic patients. J. Endocrinol. Invest. 23:428-434.

Di Sarno, A., M. L. Landi, P. Marzullo, C. Di Somma, R. Pivonello, G. Cerbone, G. Lombardi, and A. Colao. 2000. The effect of quinagolide and cabergoline, two selective dopamine receptor type 2 agonists, in the treatment of prolactinomas. Clin. Endocrinol. (Oxf.) 53:53-60

Dingwell, R. T., D. F. Kelton, K. E. Leslie, and V. L. Edge. 2001. Deciding to dry-off: does level of production matter? Deciding to dry-off: Does level of production matter? Pages 69-79 in Natl. Mastitis Counc. Annual Mtg. Proc., Ontario, Canada. National Mastitis Council, Arlington, VA.

Dingwell, R. T., K. E. Leslie, Y. H. Schukken, J. M. Sargeant, L. L. Timms, T. F. Duffield, G. P. Keefe, D. F. Kelton, K. D. Lissemore, and J. Conklin. 2004. Association of cow and quarter-level factors at drying-off with new intramammary infections during the dry period. Prev. Vet. Med. 63:75-89.

Dohoo, I. R., S. W. Martin, and H. Stryhn. 2009. Veterinary Epidemiologic Research. 2nd ed. University of Prince Edward Island. Charlottetown, PEI, Canada.

European Commission Health and Consumers Directorate-General. 2016. EudraLex Volume 5 - Pharmaceutical legislation for medicinal products for veterinary use. Brussels. https://ec.europa.eu/ health/documents/eudralex/vol-5_en.

Fernandez, G., P. Alvarez, F. San Primitivo, and L. F. de la Fuente. 1995. Factors affecting variation of udder traits of dairy ewes. J. Dairy Sci. 78:842-849.

Fitzpatrick, C. E., N. Chapinal, C. S. Petersson-Wolfe, T. J. DeVries, D. F. Kelton, T. F. Duffield, and K. E. Leslie. 2013. The effect of meloxicam on pain sensitivity, rumination time, and clinical signs in dairy cows with endotoxin-induced clinical mastitis. J. Dairy Sci. 96:2847-2856.

Giusti, M., E. Porcella, A. Carraro, M. Cuttica, S. Valenti, and G. Giordano. 1994. A cross-over study with the two novel dopaminergic drugs cabergoline and quinagolide in hyperprolactinemic patients. J. Endocrinol. Invest. 17:51-57.

Gobello, C., R. L. de la Sota, and R. G. Goya. 2001. Study of the change of prolactin and progesterone during dopaminergic agonist treatments in pseudopregnant bitches. Anim. Reprod. Sci. $66: 257-267$.

Graf, G. C., and D. M. Lawson. 1968. Factors affecting intramammary pressures. J. Dairy Sci. 51:1672-1675.

Harvey, M. J. A., A. Cauvin, M. Dale, S. Lindley, and R. Ballabio. 1997. Effect and mechanisms of the anti-prolactin drug cabergoline on pseudopregnancy in the bitch. J. Small Anim. Pract. $38: 336-339$.

Hurley, W. L. 1989. Mammary gland function during involution. J. Dairy Sci. 72:1637-1646.

Jingar, S., R. K. Mehla, M. Singh, and A. K. Roy. 2014. Lactation curve pattern and prediction of milk production performance in crossbred cows. J. Vet. Med. 2014:814768. https://doi. org $/ 10.1155 / 2014 / 814768$.

Jöchle, W., R. Ballabio, and E. di Salle. 1987. Inhibition of lactation in the Beagle bitch with the prolactin inhibitor cabergoline (FCE 21336): Dose response and aspects of long-term safety. Theriogenology 27:799-810.

Kim, I.-H., and G.-H. Suh. 2003. Effect of the amount of body condition loss from the dry to near calving periods on the subsequent body condition change, occurrence of postpartum diseases, metabolic parameters and reproductive performance in Holstein dairy cows. Theriogenology 60:1445-1456.

Kirscher, F., R. M. Bruckmaier, C. Spadavecchia, K. Friedli, M. G. Doherr, C. Syring, and A. Steiner. 2012. Quantitative assessment of physiological and behavioural parameters in healthy dairy cows 
evoked by transcutaneous electrical nerve stimulation of the udder. Vet. J. 192:183-188.

Klaas, I. C., C. Enevoldsen, M. Vaarst, and H. Houe. 2004. Systematic clinical examinations for identification of latent udder health types in Danish dairy herds. J. Dairy Sci. 87:1217-1228.

Lacasse, P., V. Lollivier, F. Dessauge, R. M. Bruckmaier, S. Ollier, and M. Boutinaud. 2012. New developments on the galactopoietic role of prolactin in dairy ruminants. Domest. Anim. Endocrinol. 43:154-160.

Leitner, G., S. Jacoby, E. Maltz, and N. Silanikove. 2007. Casein hydrolyzate intramammary treatment improves the comfort behavior of cows induced into dry-off. Livest. Sci. 110:292-297.

Leitner, G., U. Merin, and N. Silanikove. 2011. Effects of glandular bacterial infection and stage of lactation on milk clotting parameters: Comparison among cows, goats and sheep. Int. Dairy J. 21:279-285.

Lucy, M. C. 2001. Reproductive loss in high-producing dairy cattle: where will it end? J. Dairy Sci. 84:1277-1293.

Natzke, R. P., R. W. Everett, and D. R. Bray. 1975. Effect of drying off practices on mastitis infection. J. Dairy Sci. 58:1828-1835.

O'Driscoll, K., D. Gleeson, B. O'Brien, and L. Boyle. 2011. Does omission of a regular milking event affect cow comfort? Livest. Sci. 138:132-143.

O'Rourke, D. 2009. Nutrition and udder health in dairy cows: A review. Ir. Vet. J. 62(Suppl 4):S15-20.

Odensten, M. O., Y. Chilliard, and K. Holtenius. 2005. Effects of two different feeding strategies during dry-off on metabolism in highyielding dairy cows. J. Dairy Sci. 88:2072-2082.

Odensten, M. O., K. Holtenius, and K. P. Waller. 2007. Effects of two different feeding strategies during dry-off on certain health aspects of dairy cows. J. Dairy Sci. 90:898-907.

Oliver, S. P., and L. M. Sordillo. 1989. Approaches to the manipulation of mammary involution. J. Dairy Sci. 72:1647-1664.

Ollier, S., X. Zhao, and P. Lacasse. 2013. Effect of prolactin-release inhibition on milk production and mammary gland involution at drying-off in cows. J. Dairy Sci. 96:335-343.

Ollier, S., X. Zhao, and P. Lacasse. 2014. Effects of feed restriction and prolactin-release inhibition at drying off on metabolism and mammary gland involution in cows. J. Dairy Sci. 97:4942-4954.

Ollier, S., X. Zhao, and P. Lacasse. 2015. Effects of feed restriction and prolactin-release inhibition at drying-off on susceptibility to new intramammary infection in cows. J. Dairy Sci. 98:221-228.

Pezeshki, A., A. V. Capuco, B. De Spiegeleer, L. Peelman, M. Stevens, R. J. Collier, and C. Burvenich. 2010. Review article: An integrated view on how the management of the dry period length of lactating cows could affect mammary biology and defence. J. Anim. Physiol. Anim. Nutr. (Berl.) 94:e7-e30.

Ponchon, B., P. Lacasse, N. Silanikove, S. Ollier, and X. Zhao. 2014. Effects of intramammary infusions of casein hydrolysate, ethylene glycol-bis( $\beta$-aminoethyl ether)-N,N, $\mathrm{N}^{\prime}, \mathrm{N}^{\prime}$-tetraacetic acid, and lactose at drying-off on mammary gland involution. J. Dairy Sci. 97:779-788.

Prajapati, B., M. Dunne, and R. Armstrong. 2010. Sample size estimation and statistical power analyses. Optom. Today 50:16.
Rajala-Schultz, P. J., J. S. Hogan, and K. L. Smith. 2005. Short communication: Association between milk yield at dry-off and probability of intramammary infections at calving. J. Dairy Sci. 88:577-579.

Rees, A., C. Fischer-Tenhagen, and W. Heuwieser. 2014. Evaluation of udder firmness by palpation and a dynamometer. J. Dairy Sci. 97:3488-3497.

Rovai, M., M. T. Kollmann, and R. M. Bruckmaier. 2007. Incontinentia lactis: Physiology and anatomy conducive to milk leakage in dairy cows. J. Dairy Sci. 90:682-690.

Rutherford, K. M. D. 2002. Assessing pain in animals. Anim. Welf. 11:31-53.

Schukken, Y. H., J. Vanvliet, D. Vandegeer, and F. J. Grommers. 1993. A randomized blind trial on dry cow antibiotic infusion in a low somatic cell count herd. J. Dairy Sci. 76:2925-2930.

Silanikove, N., U. Merin, F. Shapiro, and G. Leitner. 2013. Early mammary gland metabolic and immune responses during natural-like and forceful drying-off in high-yielding dairy cows. J. Dairy Sci. 96:6400-6411.

Silanikove, N., F. Shapiro, A. Shamay, and G. Leitner. 2005. Role of xanthine oxidase, lactoperoxidase, and NO in the innate immune system of mammary secretion during active involution in dairy cows: manipulation with casein hydrolyzates. Free Radic. Biol. Med. 38:1139-1151.

Thornton, P. K. 2010. Livestock production: Recent trends, future prospects. Philos. Trans. R. Soc. Lond. B Biol. Sci. 365:2853-2867.

Tucker, C. B., S. J. Lacy-Hulbert, and J. R. Webster. 2009. Effect of milking frequency and feeding level before and after dry off on dairy cattle behavior and udder characteristics. J. Dairy Sci. 92:3194-3203.

Tucker, H. A., R. P. Reece, and R. E. Mather. 1961. Udder capacity estimates as affected by rate of milk secretion and intramammary pressure. J. Dairy Sci. 44:1725-1732.

Tuyttens, F. A. M., S. de Graaf, J. L. T. Heerkens, L. Jacobs, E. Nalon, S. Ott, L. Stadig, E. Van Laer, and B. Ampe. 2014. Observer bias in animal behaviour research: Can we believe what we score, if we score what we believe? Anim. Behav. 90:273-280.

Valizaheh, R., D. M. Veira, and M. A. G. von Keyserlingk. 2008. Behavioural responses by dairy cows provided two hays of contrasting quality at dry-off. Appl. Anim. Behav. Sci. 109:190-200.

Waage, S., S. Sviland, and S. A. Ødegaard. 1998. Identification of risk factors for clinical mastitis in dairy heifers. J. Dairy Sci. 81:12751284.

Wheelock, J. V., A. Smith, F. H. Dodd, and R. L. J. Lyster. 1967. Changes in the quantity and composition of mammary gland secretion in the dry period between lactations: I. The beginning of the dry period. J. Dairy Res. 34:1-12.

Zobel, G., K. Leslie, D. M. Weary, and M. A. G. von Keyserlingk. 2013. Gradual cessation of milking reduces milk leakage and motivation to be milked in dairy cows at dry-off. J. Dairy Sci. 96:5064-5071.

Zobel, G., D. M. Weary, K. E. Leslie, and M. A. G. von Keyserlingk 2015. Invited review: Cessation of lactation: Effects on animal welfare. J. Dairy Sci. 98:8263-8277. 